\title{
CALGARY AREA BLUEBIRD TRAILS 1979
}

DONALD J. STILES, 20 Lake Wapta Rise SE, Calgary, Alberta, T2J 2 M9.

The following article gives the results for 1979 of Harold Pinel's Calgary Bluebird Trail, which has been published in Blue Jay since 1974. In addition, it adds the results of two recent trails, one of these maintained by Andrew Stiles is now at 165 houses, with 60 in the Priddis area near Calgary, and 105 in the Didsbury area north of Calgary. This trail was started in 1977 when Andrew was 11 years old. The second trail of 100 houses was started by Blake Stillings in the Cochrane area as a retirement project (see map). Harold Pinel's Trail was taken over in 1979 by the Calgary Field Naturalists' Society. It was divided into sections of about 50 houses each and handled by different people. Available manpower did not permit replacing of vandalized houses or covering the complete trail. However, 309 of the 400 houses were covered and the results listed in Table 1.

Our schedule:

1. March or early April - Set up new houses. Cleaned out old houses and sprayed with a $10 \%$ creolin solution.

2. May 24 + 1 week. Counted Mountain Bluebird eggs.

3. June $15+1$ week. Counted and banded bluebird young, and counted Tree Swallow eggs.

4. July $4+1$ week. Counted and banded Tree Swallow young, and looked for second broods of bluebirds.

5. Early August. Made a last check of the nests to look for infertile eggs, dead young and late Tree Swallow broods.

These steps were generally followed except for number 5 which was done for only a small portion of the houses.

Table 1 gives this year's results. Andrew Stiles' Priddis trail with 5.76 bluebird young fledged per successful nest is higher than normal. Blake Stillings trail with 5.74 Tree Swallow young fledged per successful nest is at the higher end of the expected range.

One interesting event for the year was a nest with five Tree Swallow eggs and three bluebird eggs. The swallow pair successfully raised this mixed brood. Another interesting event was finding 13 Tree Swallow eggs in one box. There was no nest built and, of course, no eggs hatched.

The habitat where bluebirds are found on the above trails are aspen poplar with grass (parklike) and less than $50 \%$ cultivated. This suggests that bluebirds need aspen for shelter, but also need pasture for insects. Open pasture areas with no trees, such as south of Turner Valley, had no bluebirds. Similarly, heavily cultivated areas, such as near Didsbury, have no bluebirds.

The Swallows, on the other hand, are found on all parts of the trails suggesting that they can use a much more varied habitat. House Wrens are found locally where tree growth is thickest. House Sparrows are most 


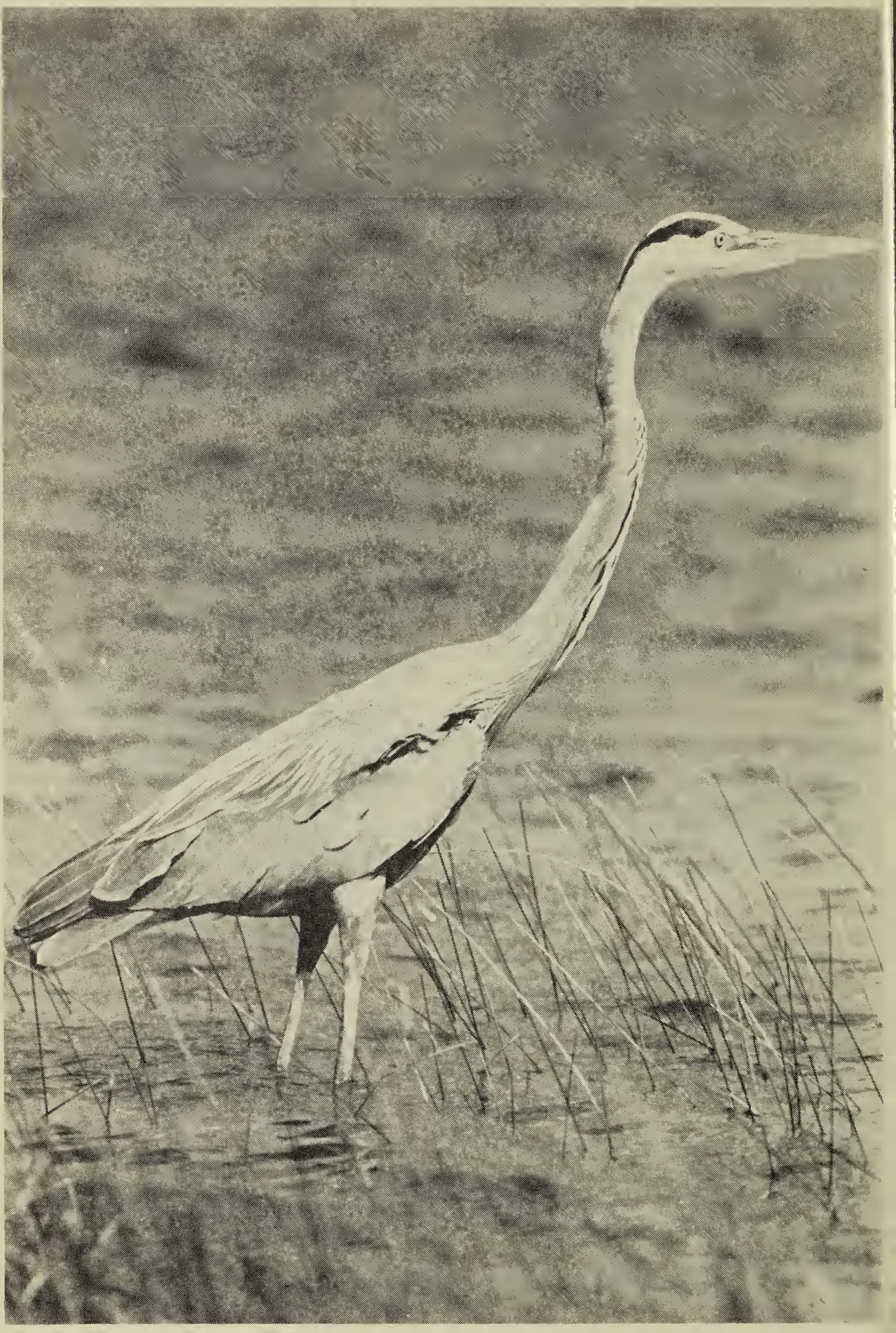

